\title{
Penerapan Mobile-First Design pada Antarmuka Website Profil Sekolah Menggunakan Metode Human-Centred Design (Studi Kasus: SMPN 21 Malang)
}

\author{
Adnan Zulkarnain \\ STIKI Malang \\ email: adnan.zulkarnain@stiki.ac.id
}

\begin{abstract}
ABSTRAK. Sekolah dapat memanfaatkan kemajuan teknologi dengan cara membuat website profil sekolah. Website profil sekolah bisa digunakan oleh sekolah sebagai media promosi dan penyebaran informasi. Selama ini tampilan website profil sekolah SMPN21 Malang dibuat seadanya, tampilan yang tidak menarik, serta kecepatan aksesnya yang begitu lambat. Tampilan website profil sekolah yang tidak menarik serta kecepatan akses yang lambat memberikan kesan bahwa SMPN21 Malang tidak serius dalam pemanfaatan kemajuan teknologi. Dari permasalahan yang dimiliki oleh SMPN21 Malang maka diperlukan perubahan pada website profil sekolah yang dimiliki. Pada penelitian ini dilakukan penerapan teknik mobile-first design antarmuka website profil sekolah SMPN21 Malang menggunakan metode pengembangan antarmuka yaitu Human-Centred Design. Hasil pengujian usability testing menunjukkan tingkat kebergunaan desain prototype antarmuka yang sudah dibuat memiliki rata-rata $86,66 \%$. Sedangkan hasil pengujian kecepatan aksesnya rata-ratanya adalah 2,66 detik.
\end{abstract}

Kata Kunci: website profil sekolah; human-centred design; usability testing;

ABSTRACT. Schools can use technological advances by creating a school profile website. The school profile website can be used by schools as a promotional media and provide information. All this time, the website profile of SMPN21 Malang's school profile has been made improperly, its appearance is not attractive, and its access speed is so slow. The appearance of an unattractive school profile website and slow access speeds give the impression that SMPN21 Malang is not serious about using technology. From the problems that are owned by SMPN21 Malang, it is necessary to change the website profile of the school they have. In this research, the application of mobile-first interface design for the SMPN21 Malang school profile website was implemented using the interface development method, Human-Centered Design. Usability testing results show the usability of the prototype interface design that has been made has an average of $86.66 \%$. While the results of testing the average access speed is 2.66 seconds.

Keywords: school profile website; human-centred design; usability testing;

\section{PENDAHULUAN}

Di era digital ini dapat kita lihat dengan jelas perilaku masyarakat yang sangat bergantung pada gadget. Dimanapun dan kapanpun setiap orang tidak bisa lepas dengan yang namanya smartphone. Ditambah lagi, kehadiran internet memudahkan kita untuk mengakses informasi dalam hitungan detik. Hal ini mulai disadari oleh banyak pihak, tidak terkecuali sekolah.

Banyak sekolah yang kini mulai memanfaatkan kemajuan teknologi dan informasi sebagai media promosi dan penyebaran informasi sekolah. Salah satunya dengan membuat website sekolah. Tidak seperti pelaku bisnis, sebagian besar website sekolah dibuat seadanya, tampilannya biasa, banyak informasi yang tidak ditampilkan, kecepatan aksesnya lambat. Tampilan website yang biasa menyimpan kesan bahwa sekolah tidak serius. Informasi sekolah yang tidak banyak ditampilkan menjadikan website tidak berguna. Selain itu, akses website yang lambat dapat membuat pengguna lari ke sekolah lain. Salah satu sekolah yang mengalami masalah ini adalah SMPN 21 Malang.

Hal tersebut dapat diatasi dengan menata ulang website SMPN 21 Malang dengan menggunakan konsep responsive web design. Responsive web design memberikan praktik terbaik bagi pengguna saat mengakses website melalui smartphone, tablet, dan laptop disamping desktop (Baturay \& Birtane, 2013). Responsive web design terdiri dari dua teknik yaitu mobile-first design dan desktop-first design. Mobile-first design merupakan teknik mendesain antarmuka website pada tampilan mobile, baru setelahnya ada penyesuaian tampilan pada desktop, sebaliknya, pada desktop-first design, antarmuka website didesain pada tampilan desktop terlebih dulu baru dilakukan penyesuaian pada tampilan mobile (Alnawaj'ha \& Abutaha, 2018). 
Hampir sebagian besar orang mengakses informasi melalui smartphone. Ketika website didesain menggunakan konsep desktop-first design maka para pengguna smartphone akan menerima tampilan dengan ukuran data yang besar. Hal ini akan memperlambat pengguna untuk mencapai website yang dituju. Berbeda dengan desktop-first design, website yang dibuat menggunakan konsep mobile-first design membuat pengguna lebih cepat dalam mengakses website yang dituju, karena ukuran datanya lebih kecil.

Oleh karena itu, melalui penelitian ini, akan dibangun sebuah website sekolah dengan menggunakan konsep mobile-first design dengan studi kasus pada SMPN 21 Malang. Harapannya, pengguna mampu mengakses website SMPN 21 Malang dengan cepat dan mendapatkan informasi yang dibutuhkan. Selain itu, SMPN 21 Malang mampu melakukan promosi secara online dengan memanfaatkan website sekolah.

\section{METODOLOGI PENELITIAN}

Pada penelitian ini metodologi penelitian yang digunakan adalah Human-CentredDesign (HCD) berpedoman pada literatur ISO 9241-210 (International Organization for Standardization, 2019).

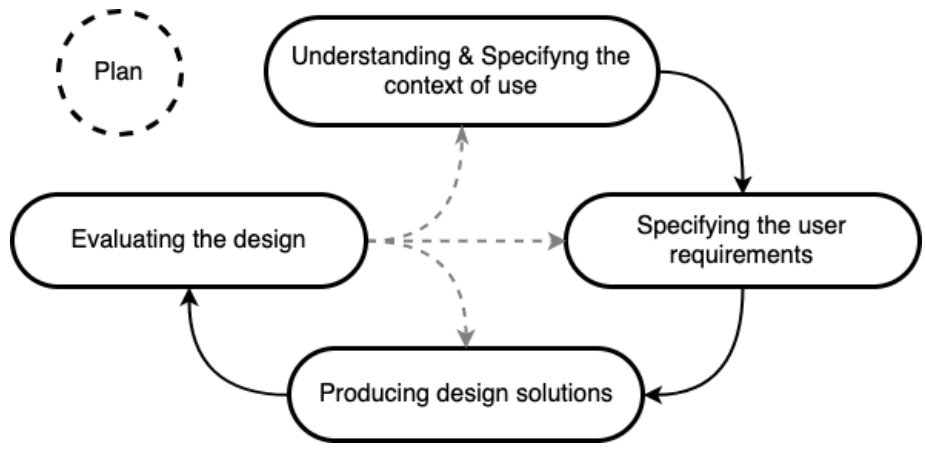

Gambar 1. Tahapan Human-Centred Design (ISO 9241-210:2019)

\section{Tahap Plan}

Tahapan awal yang dilakukan adalah tahap plan atau perencanaan. Tahapan ini dilakukan sebagai awalan serta persiapan sebelum melangkah ke tahapan selanjutnya pada metode Human-CentredDesign. Pada tahap plan dilakukan proses wawancara dan observasi. Wawancara dilakukan untuk memahami kebutuhan data terkait pembuatan antarmuka yang akan dilakukan serta mengetahui gambaran kondisi saat ini. Proses wawancara dilakukan kepada kepala sekolah, admin website sekolah dan guru.

Tabel 1. Hasil Wawancara \& Observasi

\begin{tabular}{|l|l|l|}
\hline \multicolumn{1}{|c|}{ Pertanyaan } & \multicolumn{1}{|c|}{ Kondisi saat ini } & \multicolumn{1}{c|}{ Harapan } \\
\hline $\begin{array}{l}\text { Bagaimana tampilan website } \\
\text { profil sekolah saat ini? }\end{array}$ & $\begin{array}{l}\text { Website terlihat kuno, tidak } \\
\text { menarik }\end{array}$ & $\begin{array}{l}\text { Website terlihat lebih modern dan } \\
\text { menarik serta mencerminkan visi } \\
\text { dari sekolah. }\end{array}$ \\
\hline $\begin{array}{l}\text { Apakah website terlihat bagus } \\
\text { ketika dibuka menggunakan } \\
\text { smartphone? }\end{array}$ & $\begin{array}{l}\text { Website terlihat berantakan } \\
\text { ketika dibuka di smartphone dan } \\
\text { font terlalu kecil, sehingga sulit } \\
\text { dibaca }\end{array}$ & $\begin{array}{l}\text { Website terlihat rapi dan } \\
\text { porposional ketika dibuka di } \\
\text { smartphone serta font mudah } \\
\text { dibaca }\end{array}$ \\
\hline $\begin{array}{l}\text { Berapa jumlah views pengunjung } \\
\text { website perbulannya? }\end{array}$ & Dibawah 1000 views & Bisa lebih dari 2000 views \\
\hline Berapa kecepatan akses nya? & Kurang lebih diatas 6 detik & Biasa diakses dibawah 3 detik \\
\hline
\end{tabular}

\section{Tahap Understanding \& Specifyng the content use}

Tahap ini bertujuan untuk memahami siapa saja yang akan menggunakan website dan mengerti bagaimana karakternya. Tahap ini terdiri dari dua proses yaitu Proses Identifikasi User \& Karakter user.

\section{Idenfikasi user}

Hasil identifikasi user yang dilakukan adalah sebagai berikut: 
a. Orang tua wali atau calon orang tua wali, yaitu orang tua murid yang nantinya akan mengakses informasi atau pengumuman dari sekolah.

b. Siswa, yaitu pelajar yang akan menggunakan website sebagai sarana informasi terkait sekolah.

c. Guru, yaitu pendidik yang akan memberi informasi atau pengumuman melalui website sekolah.

\section{Karakter user}

Setelah memahami siapa saja yang menggunakan website sekolah, tahap selanjutnya adalah memahami karakter user. Karakter user pada website sekolah ini adalah :

Tabel 2. Karakter user

\begin{tabular}{|l|l|}
\hline Jenis & Keterangan \\
\hline Usia & Orang tua wali : 35-40 tahun \\
& Siswa : 13-15 tahun \\
& Guru : 30-55 tahun \\
\hline $\begin{array}{l}\text { Pengalaman menggunakan komputer, smartphone } \\
\text { dan internet. }\end{array}$ & $\begin{array}{l}\text { Sebagian besar } \text { user terbiasa dan bisa } \\
\text { mengoperasikan komputer, smartphone dan } \\
\text { menggunakan internet. }\end{array}$ \\
\hline
\end{tabular}

\section{Tahap Specifyng the user requirements}

Pada tahap ini bertujuan untuk memahami kebutuhan user. Cara yang dilakukan adalah mewawancarai beberapa user sehingga didapatkan kesimpulan kebutuhan user.

Tabel 3.User Requirements

\begin{tabular}{|c|c|}
\hline User & Kebutuhan \\
\hline Orang Tua & $\begin{array}{l}\text { 1. Dapat mengetahui profil sekolah } \\
\text { 2. Dapat mengetahui informasi terkait kurikulum } \\
\text { 3. Dapat mengetahui informasi sarana prasarana } \\
\text { 4. Dapat menghubungi pihak sekolah } \\
\text { 5. Dapat mengetahui informasi kegiatan sekolah } \\
\text { 6. Dapat mengetahui jadwal kegiatan sekolah } \\
\text { 7. Dapat mengetahui statistik jumlah guru, jumlah siswa, jumlah alumni } \\
\text { 8. Dapat mengetahui peta atau lokasi SMPN } 21 \text { Malang }\end{array}$ \\
\hline Siswa & $\begin{array}{l}\text { 1. Dapat melakukan pendaftaran ke website } \\
\text { 2. Dapat masuk ke website } \\
\text { 3. Dapat membaca profil sekolah } \\
\text { 4. Dapat mengetahui informasi kurikulum } \\
\text { 5. Dapat memahami apa saja sarana prasarana sekolah } \\
\text { 6. Dapat mengathui jadwal kegiatan sekolah } \\
\text { 7. Dapat mengetahui statistik jumlah guru, jumlah siswa, jumlah alumni } \\
\text { 8. Dapat mengetahui peta atau lokasi sekolah } \\
\text { 9. Dapat menghubungi pihak sekolah } \\
\text { 10. Dapat mengetahui informasi kegiatan sekolah } \\
\text { 11. Dapat memberikan komentar }\end{array}$ \\
\hline Guru & $\begin{array}{l}\text { 1. Dapat memasukkan data profil sekolah } \\
\text { 2. Dapat memasukkan data informasi terkait kurikulum } \\
\text { 3. Dapat memasukkan data informasi sarana prasarana } \\
\text { 4. Dapat memasukkan data informasi kegiatan sekolah } \\
\text { 6. Dapat memasukkan data jadwal kegiatan sekolah } \\
\text { 7. Dapat memasukkan data statistik jumlah guru, jumlah siswa, jumlah alumni } \\
\text { 8. Dapat menjawab pertanyaan dari pengunjung website }\end{array}$ \\
\hline
\end{tabular}

\section{Tahap Producing design solutions}

Tahap ini bertujuan untuk merancang serta melakukan implementasi desain yang sudah dibuat. Pada penelitian ini menerapkan konsep mobile-first design untuk membuat desain antarmuka, sehingga pembuatan desain akan dimulai dari rancangan bentuk mobile. 


\section{Membuat wireframe}

Pembuatan wireframe merupakan tahapan paling dasar dalam membuat desain. Wireframe dibuat secara manual menggunakan pulpen dan kertas. Tipe wireframe yang dibuat adalah low-fidelitywireframe, dimana hasil desain wireframe akan memiliki tingkat kemiripan yang rendah dengan prototype yang akan dibuat ditahap selanjutnya. Keuntungan menggunakan tipe low-fidelity wireframe adalah proses pembuatannya lebih cepat dibandingkan dengan high-fidelity wireframe (Hartson \& Pyla, 2019). Hasil dari pembuatan wireframe adalah sebagai berikut:
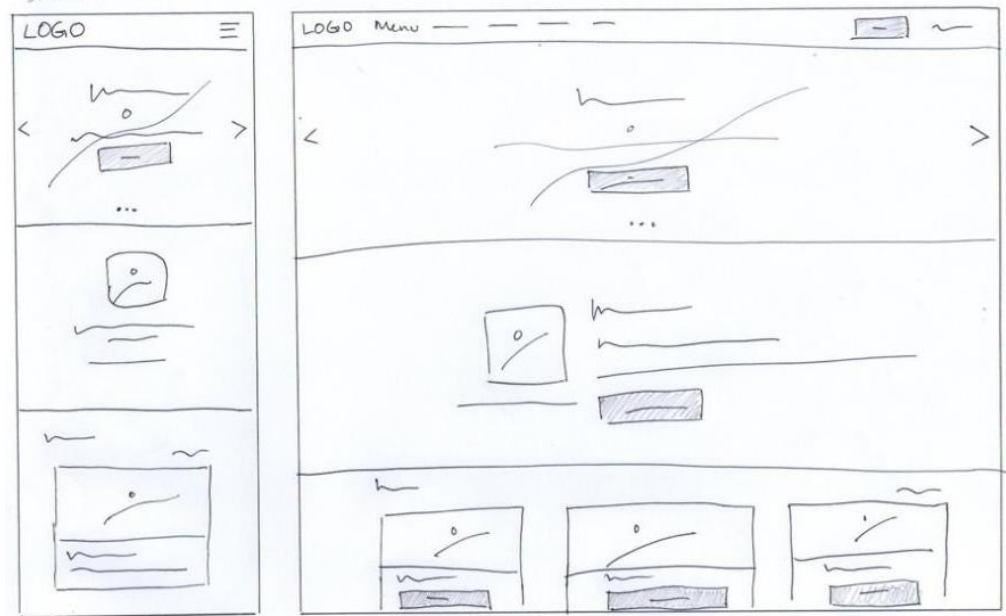

Gambar 2. Wireframe Beranda
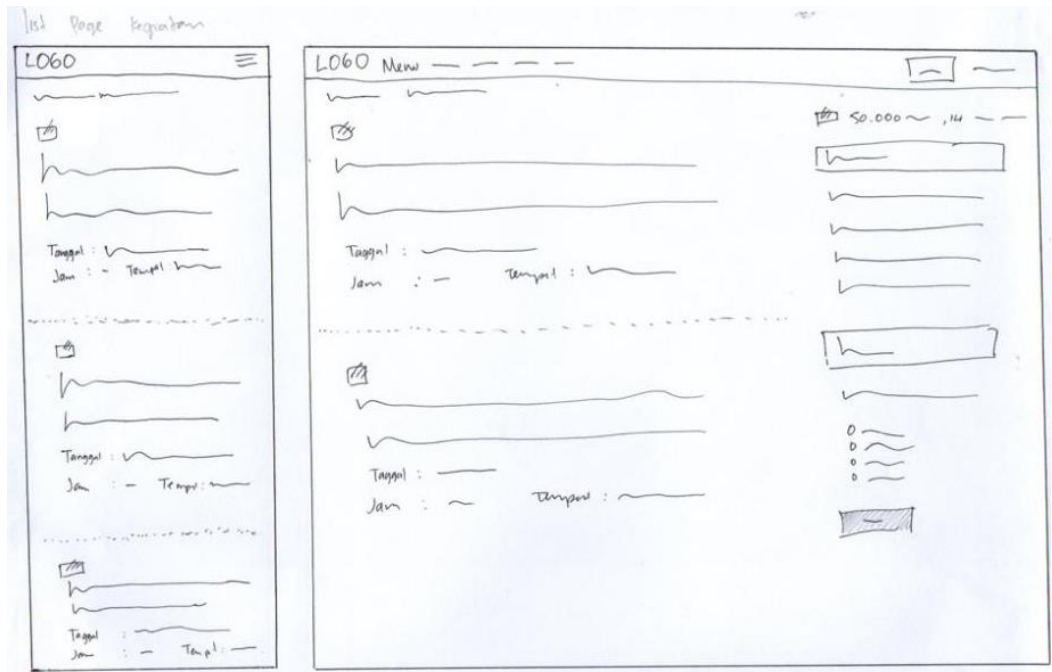

Gambar 3. Wireframe List Page 


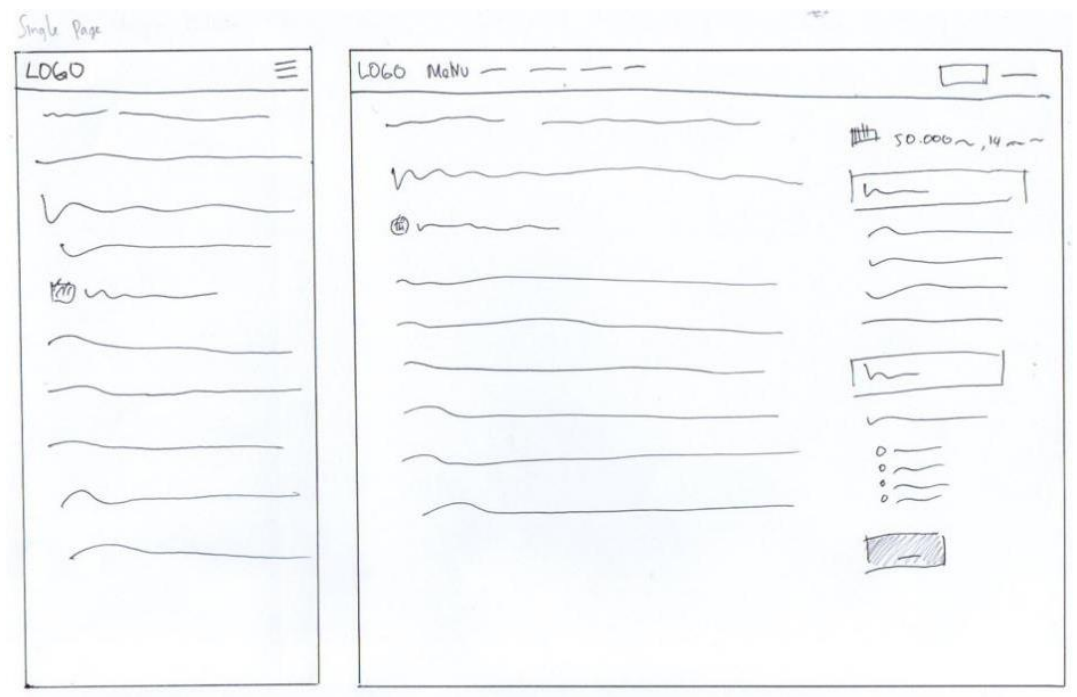

Gambar 4. Wireframe Single Page

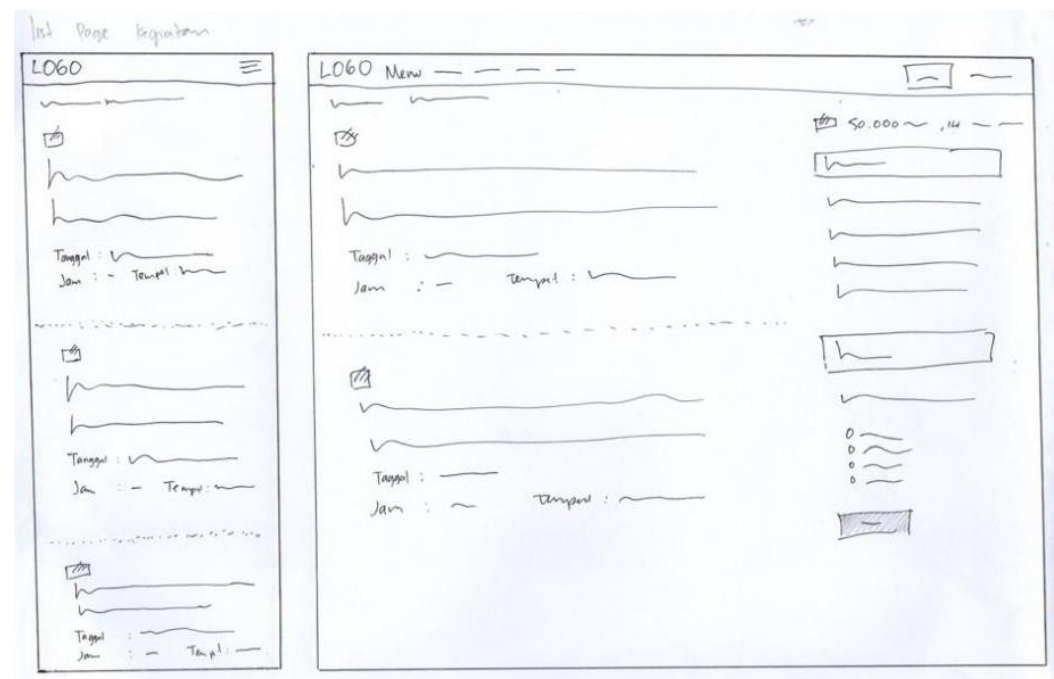

Gambar 5. List Page Kegiatan

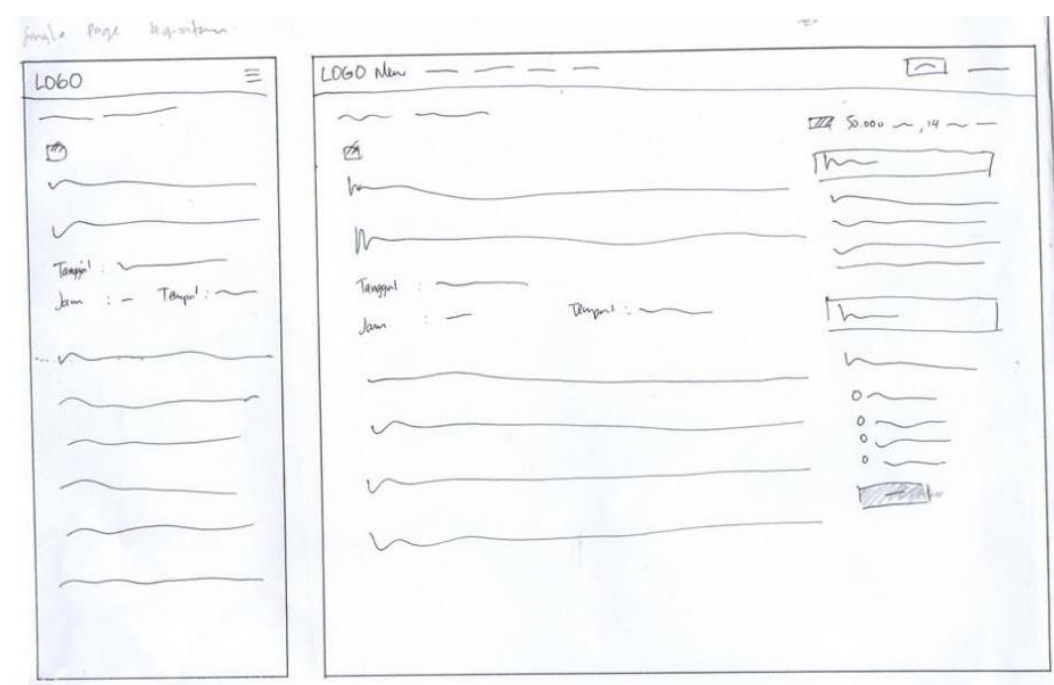

Gambar 6. Wireframe Single Page Kegiatan 


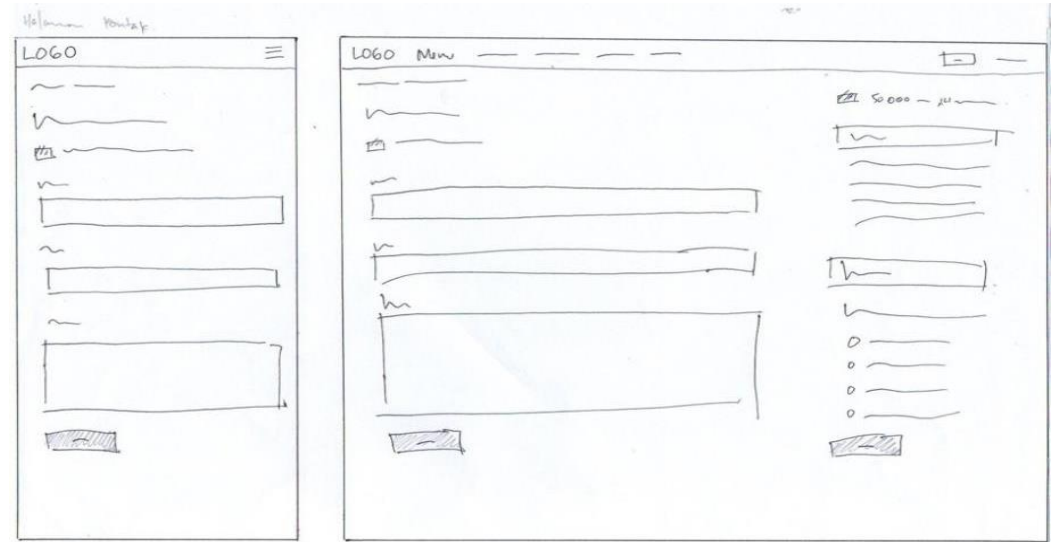

Gambar 7. Wireframe Kontak

Membuat prototype

Pada penelitian ini desain prototype merupakan versi digital dari hasil pembuatan wireframe pada tahap sebelumnya. Dalam pembuatan prototype pada penelitian ini menggunakan software yang bernama Adobe XD. Hasil dari pembuatan prototype adalah sebagai berikut :
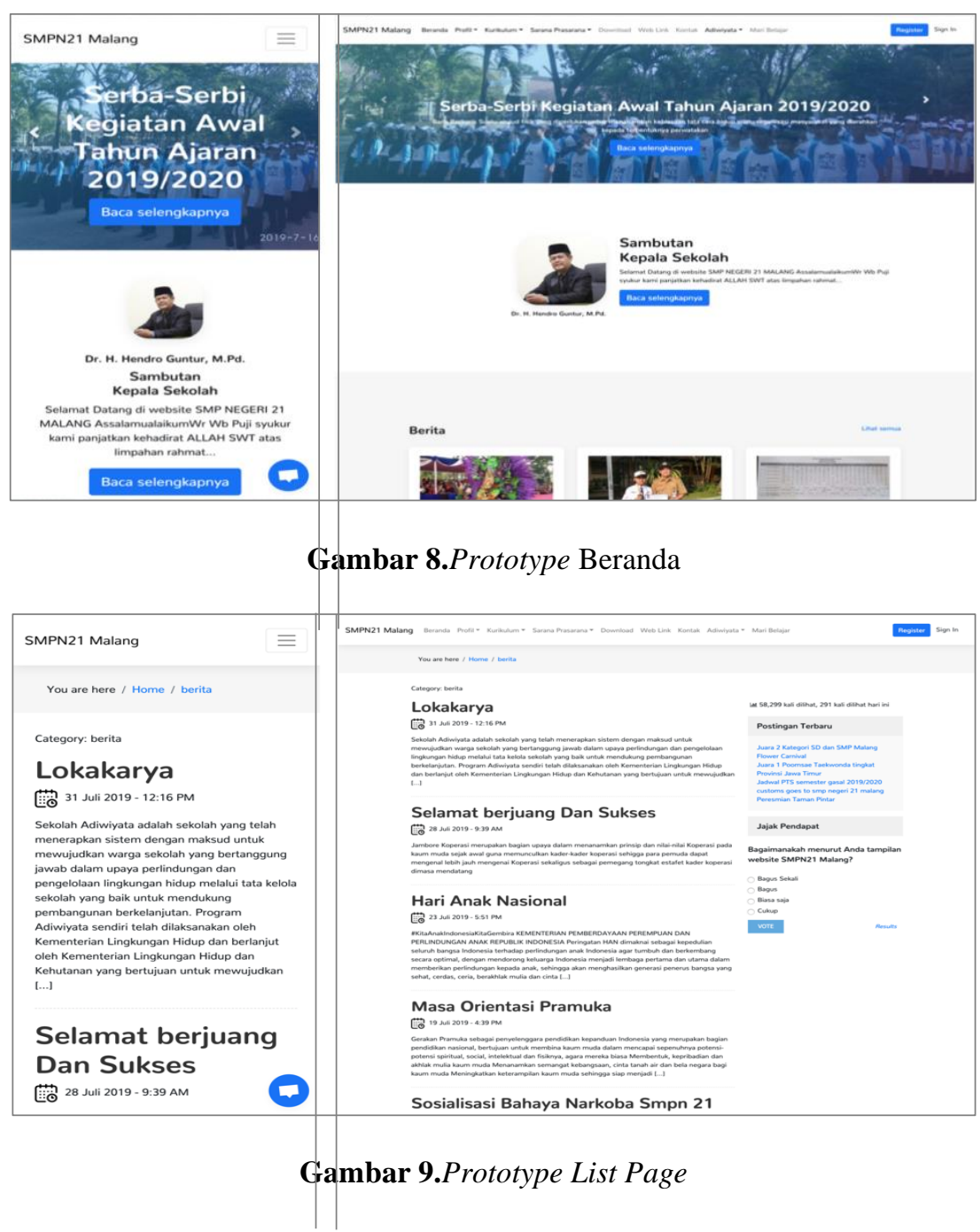


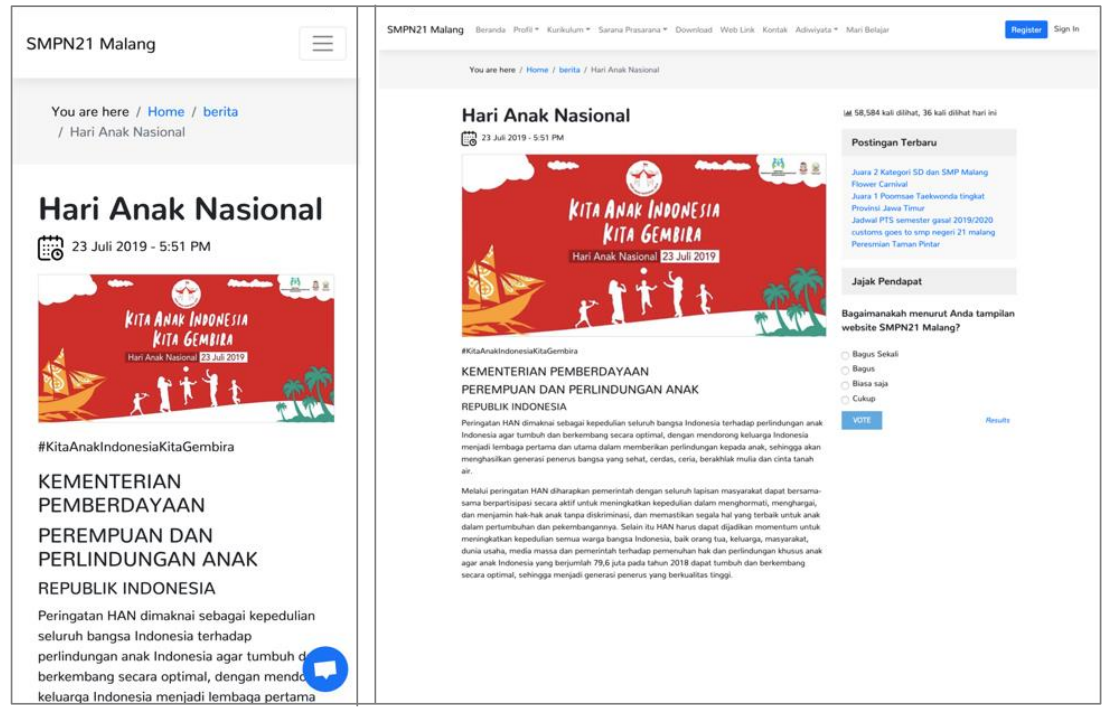

Gambar 10. Prototype Single Page

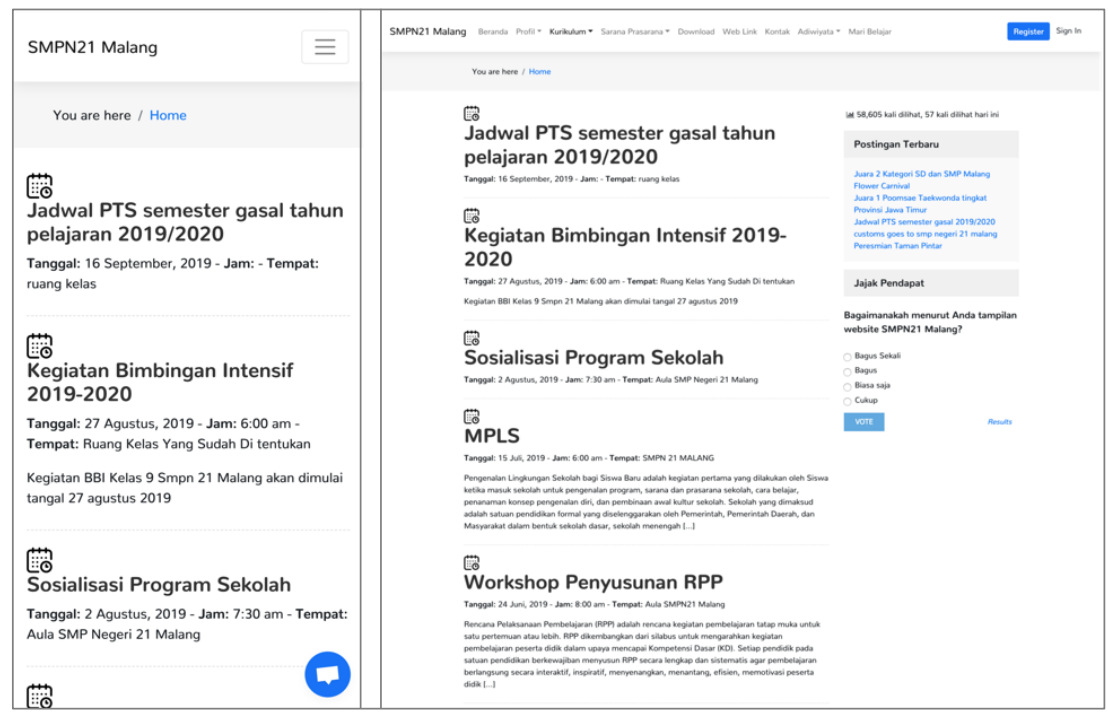

Gambar 11. Prototype List Page Kegiatan 


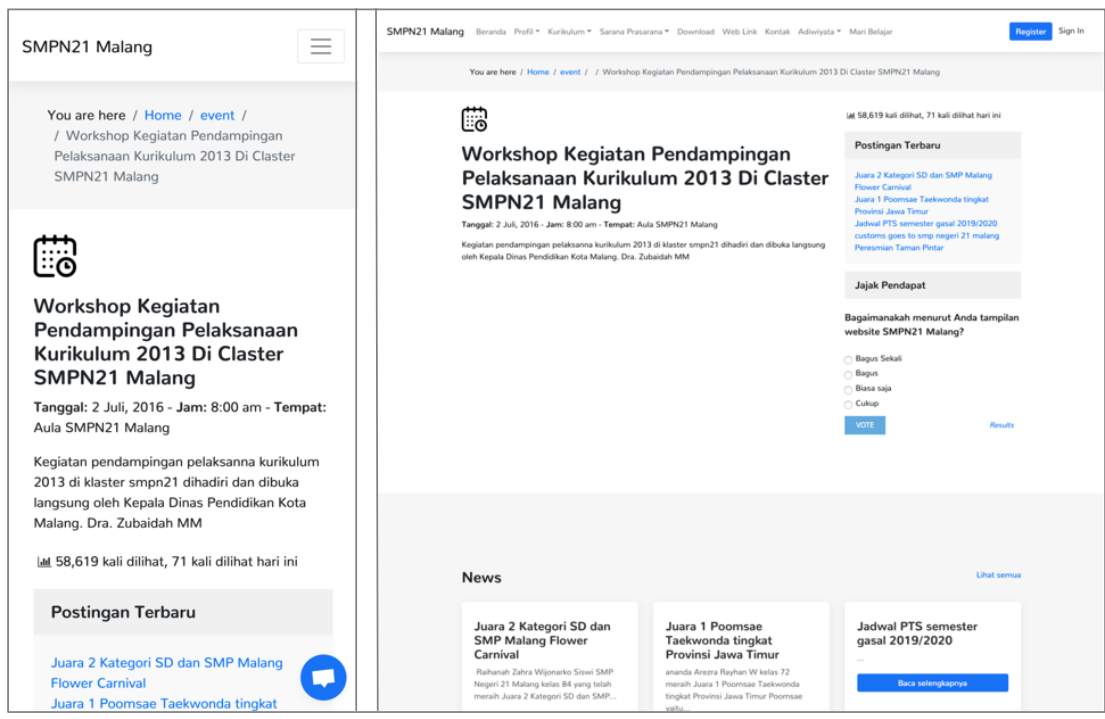

Gambar 12. Prototype Single Page Kegiatan

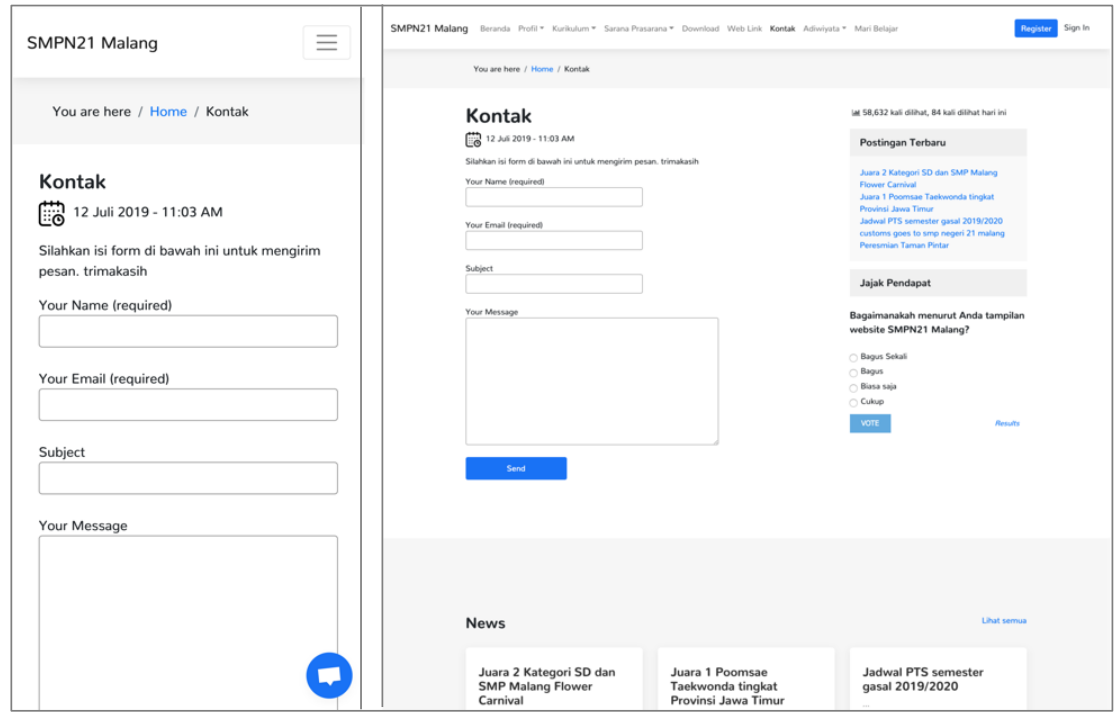

Gambar 13. Prototype Kontak

\section{Membuat HTML}

Setelah tahap pembuatan prototype selesai dilakukan, tahap selanjutnya adalah merubah desain prototype menjadi versi HTML dan CSS. Penerapan mobile-firstdesign dalam CSS menggunakan fitur CSS yang bernama mediaqueries. Untuk bisa menerapkan mobile-firstdesign maka pada file HTML harus ditambahkan baris tag html seperti berikut:

\section{$\langle$ meta name="viewport" content="width=device-width, initial-scale=1.0" >}

Kemudian pada, untuk menerapkan mobile-first pada file CSS maka perlu ditambahkan mediaqueries dengan code seperti berikut:

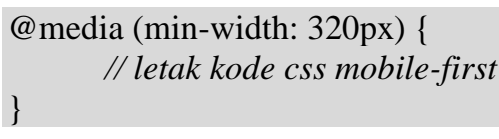


Kode css mobile-first yang diterapkan ditulis diantara deklarasi mediaqueries.

\section{Evaluating the design}

Tahap ini merupakan tahap pengujian dari desain yang sudah dibuat pada tahap sebelumnya. Pada tahap ini terdapat 2 macam pengujian yang dilakukan yaitu UsabilityTesting dan Uji Kecepatan Akses.

\section{Usability Testing}

UsabilityTesting merupakan sebuah metode untuk mengukur tingkat kegunaan sebuah website(Beny, Yani, \& Ningrum, 2019; Pendell \& Bowman, 2012). Terdapat banyak metode usabilitytesting yang bisa digunakan untuk melakukan pengujian usability. Salah satunya adalah HallwayTesting. Pada penelitian ini memilih menggunakan HallwayTesting karena bisa memilih responden pengujian secara acak sehingga prosesnya cepat dan berbiaya murah (Ritawati \& Fajar, 2019).

Langkah pertama yang dilakukan pada Hallwaytesting adalah menyiapkan skenario untuk diberikan ke user agar menggunakan aplikasi. Berikut adalah skenario pengujian yang dibuat.

Tabel 4. Skenario pengujian

\begin{tabular}{|l|l|l|}
\hline No & Nama Prototype & Skenario \\
\hline 1 & Beranda & $\begin{array}{l}\text { Dimanakah Anda bisa menemukan informasi tentang pendaftaran murid } \\
\text { baru. }\end{array}$ \\
\hline 2 & List Page & $\begin{array}{l}\text { Bagaimana caranya melihat daftar berita atau informasi yang ada di } \\
\text { SMPN21 Malang. }\end{array}$ \\
\hline 3 & Single Page & Bagaimana membaca secara detail informasi tentang kegiatan sekolah. \\
\hline 4 & List Page Kegiatan & Bagaimana caranya melihat daftar kegiatan yang ada di SMPN21 Malang. \\
\hline 5 & Single Page Kegiatan & Bagaimana membaca secara detail informasi tentang kegiatan sekolah. \\
\hline 6 & Kontak & $\begin{array}{l}\text { Bagaimana cara mengirimkan pesan ke sekolah atau hanya sekedar } \\
\text { mengirimkan kritik. }\end{array}$ \\
\hline
\end{tabular}

Tahapan kedua yang setelah menyiapkan skenario adalah membuat lembar User Result Metrics. User result metrics digunakan untuk mencatat hasil pengujian skenario.

Tabel 5.User Result Metrics

\begin{tabular}{|l|c|c|c|c|}
\hline \multicolumn{5}{|c|}{ "Nama Prototype" } \\
\hline No & Tester & Step 1 & Step 2 & Step n \\
\hline 1 & User 1 & & & \\
\hline 2 & User 2 & & & \\
\hline 3 & User 3 & & & \\
\hline 4 & User 4 & & & \\
\hline 5 & User 5 & & & \\
\hline
\end{tabular}

Pengujian Kecepatan Akses

Dalam tahapan pengujian kecepatan akses, langkah pertama yang perlu dilakukan adalah menyiapkan perangkat serta tool untuk pengujian.

Pada penelitian ini perangkat pengujian yang digunakan adalah sebuah laptop Apple Macbook Air dengan spesifikasi sebagai berikut :
a. Prosesor
$: 1,8 \mathrm{GHz}$ Intel Core i5
b. Memori
: $8 \mathrm{~GB} 1600 \mathrm{MHz}$ DDR3
c. Hardisk
: SSD $120 \mathrm{~GB}$
d. Sistem Operasi $\quad$ : MacOS Mojave 10.14.6

Sedangkan, tool yang digunakan adalah untuk melakukan pengujian kecepatan akses adalah webbrowser Google Chrome. Webbrowser Google Chrome memiliki fitur developermode yang bisa digunakan untuk melakukan pengujian kecepatan akses sebuah website. 


\section{HASIL DAN PEMBAHASAN}

\section{A. Hasil UsabilityTesting}

Hasil usabilitytesting menggunakan metode hallwaytesting adalah sebagai berikut:

Tabel 6. Hasil uji prototype "Beranda"

\begin{tabular}{|l|l|l|}
\hline \multicolumn{3}{|c|}{ Beranda } \\
\hline No & Tester & Step 1 \\
\hline 1 & User 1 & Lancar \\
\hline 2 & User 2 & Lancar \\
\hline 3 & User 3 & Lancar \\
\hline 4 & User 4 & Lancar \\
\hline 5 & User 5 & Lancar \\
\hline
\end{tabular}

Tabel 7. Hasil uji prototype "List Page"

\begin{tabular}{|l|l|l|l|}
\hline \multicolumn{4}{|c|}{ ListPage } \\
\hline No & Tester & Step 1 & \multicolumn{1}{|c|}{ Step 2 } \\
\hline 1 & User 1 & Lancar & Lancar \\
\hline 2 & User 2 & Lancar & Lancar \\
\hline 3 & User 3 & Lancar & Lancar \\
\hline 4 & User 4 & Lancar & Lancar \\
\hline 5 & User 5 & Lancar & Lancar \\
\hline
\end{tabular}

Tabel 8. Hasil uji prototype "Single Page"

\begin{tabular}{|l|l|l|l|l|}
\hline \multicolumn{5}{|c|}{ SinglePage } \\
\hline No & Tester & Step 1 & \multicolumn{1}{|c|}{ Step 2 } & Step 3 \\
\hline 1 & User 1 & Lancar & $\begin{array}{l}\text { Kurang } \\
\text { Lancar }\end{array}$ & Lancar \\
\hline 2 & User 2 & Lancar & Lancar & $\begin{array}{l}\text { Kurang } \\
\text { Lancar }\end{array}$ \\
\hline 3 & User 3 & Lancar & Lancar & Lancar \\
\hline 4 & User 4 & Lancar & Lancar & Lancar \\
\hline 5 & User 5 & Lancar & Lancar & Lancar \\
\hline
\end{tabular}

Tabel 9. Hasil uji prototype "List Page Kegiatan"

\begin{tabular}{|l|l|l|l|}
\hline \multicolumn{4}{|c|}{ List Page Kegiatan } \\
\hline No & Tester & Step 1 & \multicolumn{1}{|c|}{ Step 2 } \\
\hline 1 & User 1 & Lancar & Kurang Lancar \\
\hline 2 & User 2 & Lancar & Lancar \\
\hline 3 & User 3 & Lancar & Lancar \\
\hline 4 & User 4 & Lancar & Lancar \\
\hline 5 & User 5 & Lancar & Lancar \\
\hline
\end{tabular}

Tabel 10. Hasil uji prototype "Single Page Kegiatan"

\begin{tabular}{|l|l|c|l|l|}
\hline \multicolumn{5}{|c|}{ SinglePage Kegiatan } \\
\hline No & Tester & Step 1 & \multicolumn{1}{|c|}{ Step 2 } & Step 3 \\
\hline 1 & User 1 & Lancar & $\begin{array}{l}\text { Kurang } \\
\text { Lancar }\end{array}$ & Lancar \\
\hline 2 & User 2 & Lancar & Lancar & Lancar \\
\hline 3 & User 3 & Lancar & Lancar & Lancar \\
\hline 4 & User 4 & Lancar & Lancar & Lancar \\
\hline 5 & User 5 & Lancar & Lancar & Lancar \\
\hline
\end{tabular}


Tabel 11. Hasil uji prototype "Kontak"

\begin{tabular}{|l|l|l|l|}
\hline \multicolumn{4}{|c|}{ Kontak } \\
\hline No & Tester & Step 1 & Step 2 \\
\hline 1 & User 1 & Lancar & Lancar \\
\hline 2 & User 2 & Lancar & Lancar \\
\hline 3 & User 3 & Lancar & Lancar \\
\hline 4 & User 4 & Lancar & Lancar \\
\hline 5 & User 5 & Lancar & Lancar \\
\hline
\end{tabular}

Berikut adalah hasil Tabulasi Usability Testing :

Tabel 12. Tabulasi Usability Testing

\begin{tabular}{|l|l|l|}
\hline No & Nama Prototype & Tingkat Kebergunaan \\
\hline 1 & Beranda & $100 \%$ \\
\hline 2 & List Page & $100 \%$ \\
\hline 3 & Single Page & $60 \%$ \\
\hline 4 & List Page Kegiatan & $80 \%$ \\
\hline 5 & Single Page Kegiatan & $80 \%$ \\
\hline 6 & Kontak & $100 \%$ \\
\hline \multicolumn{2}{|r|}{ Rata-rata } & $86,66 \%$ \\
\hline
\end{tabular}

\section{B. Hasil Pengujian Kecepatan Akses.}

Hasil pengujian kecepatan akses menggunakan tooldevelopermode di Google Chrome hasilnya adalah sebagai berikut :

Tabel 13. Hasil Pengujian Kecepatan Akses

\begin{tabular}{|l|l|l|}
\hline No & Nama Prototype $(H T M L)$ & Kecepatan dalam detik \\
\hline 1 & Beranda & 3.11 \\
\hline 2 & List Page & 3.05 \\
\hline 3 & Single Page & 2.26 \\
\hline 4 & List Page Kegiatan & 3.14 \\
\hline 5 & Single Page Kegiatan & 2.10 \\
\hline 6 & Kontak & 2.00 \\
\hline \multicolumn{2}{|r|}{ Rata-rata } & 2.66 Detik \\
\hline
\end{tabular}

\section{KESIMPULAN DAN SARAN}

Berdasarkan hasil penelitian yang sudah dilakukan tentang penerapan mobile-first design pada antarmuka website profil sekolah menggunakan metode human-centreddesign (studi kasus: SMPN21 Malang) dapat disimpulkan bahwa tingkat kebergunaan desain prototype antarmuka yang sudah dibuat memiliki nilai rata-rata $86,66 \%$. Kemudian menurut hasil pengujian kecepatan akses, rata-rata kecepatan akses per halamannya adalah 2,66 detik meningkat sekitar 56\% dibandingkan sebelum diterapkan mobilefirstdesign. Serta metode pengembangan antarmuka human-centred design terbukti dapat membantu merancang antarmuka sesuai dengan keinginan pengguna.

Saran untuk pengembangan penelitian selanjutnya adalah pada tahapan usabilitytesting dapat menggunakan metode lain sehingga dapat menggali kemungkinan meningkatnya nilai kebergunaan sebuah antarmuka.

\section{DAFTAR RUJUKAN}

Alnawaj'ha, F. Y., \& Abutaha, M. S. (2018). Responsive web design commitment by the web developers in Palestine. In 2018 4th International Conference on Computer and Technology Applications, ICCTA 2018 (pp. 69-73). Institute of Electrical and Electronics Engineers Inc. https://doi.org/10.1109/CATA.2018.8398658 
Baturay, M. H., \& Birtane, M. (2013). Responsive Web Design: A New Type of Design for Webbased Instructional Content. Procedia - Social and Behavioral Sciences, 106, 2275-2279. https://doi.org/10.1016/j.sbspro.2013.12.259

Beny, B., Yani, H., \& Ningrum, G. M. (2019). Evaluasi Usability Situs Web Kemenkumham Kantor Wilayah Jambi Dengan Metode Usability Test Dan System Usability Scale. RESEARCH : Computer, Information System \& Technology Management, 2(1), 30-34. https://doi.org/10.25273/research.v2i1.4282

Hartson, R., \& Pyla, P. (2019). Prototyping. In The UX Book (pp. 405-432). Elsevier. https://doi.org/10.1016/B978-0-12-805342-3.00020-5

International Organization for Standardization. (2019). ISO 9241-210: Ergonomics of humansystem interaction - Part 210: Human-centred design for interactive systems. International Organization for Standardization. Retrieved from https://www.iso.org/standard/77520.html

Pendell, K. D., \& Bowman, M. S. (2012). Usability Study of a Library's Mobile Website: An Example from Portland State University. Information Technology and Libraries, 31(2), 45. https://doi.org/10.6017/ital.v31i2.1913

Ritawati, \& Fajar, A. N. (2019). Analysis usability and content in known system implementation. Journal of Theoretical and Applied Information Technology, 97(6), 1788-1796. 